\title{
КОНЦЕПЦИЯ БЕНЕФИЦИАРНОЙ СОБСТВЕННОСТИ: ПЕРСПЕКТИВЫ ПРИМЕНЕНИЯ В РОССИИ
}

\section{CONCEPT OF BENEFICIAL PROPERTY: PROSPECTS OF APPLICATION IN RUSSIA}

\section{Volkov}

Summary. The concept of benevolent property is based on the principles of English equity law, or even more precisely English trust law. It is from here that this concept was transplanted initially into international tax law and then into the legal systems of individual countries, including Russia.

Despite the fact that the concept of beniferous sobbinity is not formalized in Russian civil legislation, this institution has been developed in the practice of making decisions by Russian courts in civil cases.

This article attempts to investigate the characteristics and concepts of "beniferous property" and the use of appropriate uonception in Russian civil proceedings.

Keywords: beneficiary, beneficial owner, beneficial property, concept of beneficial ownership.
$\mathbf{K}$ ак уже было отмечено, концепция бенефициарной собственности проистекает из английского «права справедливости» (law of equity).

Под бенефициарным собственником (beneficial owner) принято понимать одного, или нескольких фактических владельцев какого-либо объекта, обладающих им прямо, или косвенно, либо лицо в чьем пользовании тот, или иной объект фактически находится. В отношении юридических лиц бенефициарными собственниками принято понимать юридические и физические лица, и которые могут существенно влиять на принятие таким юридическим лицом каких-либо решений. При этом бенефициарные собственники формально могут не являться владельцами соответствующего объекта, и юридически он может принадлежать другому лицу, или лицам.

Кроме того, бенефициарной собственностью (beneficial ownership) признается бенефициарный интерес в вещной (имущественной) структуре объекта трастовой собственности (trust property) [1], даже если соответствующее лицо не является формальным владельцем.
Волков Денис Сергеевич

Аспирант, Московский государственный юридический университет имени О. Е. Кутафина (МГЮА)

d.volkov.msal@gmail.com

Аннотация. Концепция такого понятия, как бенефициарная собственность базируется на принципах английского права справедливости, или еще точнее, на английском трастовом праве. Именно отсюда данная концепция трансплантировалась изначально в международное налоговое право, а затем и в правовые системы отдельных стран, включая Россию.

Несмотря на то, что концепция бенефициарной собственности в российском гражданском законодательстве не формализована, данный институт получил свое развитие в практике вынесения решений российскими судами по гражданским делам.

В настоящей статье предпринимается попытка исследования признаков и понятий «бенефициарной собственности» и использование соответствующей концепции в российском гражданском судопроизводстве.

Ключевые слова: бенефициар, бенефициарный собственник, бенефициарная собственность, концепция бенефициарной собственности.

Впервые в международном налоговом праве концепция бенефициарной собственности была использована в 1942 году, в тексте международного соглашения по вопросам налогообложения между США и Канадой одним из условий которого являлся пятипроцентный налог на дивиденды, выплачиваемые дочерним предприятием материнской компании, при условии, что все акции с полным правом голоса, исключая квалифицированные акции директоров, обеспечивающие право занимать соответствующие должности в компании, являются бенефициарной собственностью материнской фирмы[2].

На сегодняшний день официальным документом, дающим одно из наиболее полных представлений о понятии «бенефициарный собственник» можно считать Модельную конвенцию о налогах на доходы и капитал Организации Экономического сотрудничества и развития (далее - модельная конвенция ОЭСР) [3], а также Комментарии к данной концепции. Анализ указанного документа, позволяет однозначно констатировать, что понятие бенефициарной собственности было заимствовано Организацией экономического сотрудничества (далее - ОЭСР) ни сама упомянутая Модельная конвенция 
ОЭСР, ни Комментарии к ней четкого определения, что такое бенефициарный собственник не содержат, а всего лишь перечисляют категории субъектов, которые точно бенефициарными собственниками дохода не признаются (агенты, номинальные владельцы, кондуитные компании и т.п.).

Таким образом, основной недостаток концепции бенефициарного права в современных правовых условиях заключается в отсутствии законодательно закрепленного, формализованного определения термина «бенефициарный собственник» и «бенефициарная собственность», что не только делает данную концепцию весьма размытой, открывая возможности для определенного рода злоупотреблений в ряде спорных ситуаций.

Согласно пункту 2 статьи 3 выше упомянутой Модельной Конвенции ОЭРР, в случае отсутствия в тексте международного соглашения о избежании двойного налогообложения, заключенного между теми, или иными государствами определения тех, или иных терминов, используется значение данных терминов, которое им придается в национальном налоговом законодательстве (если их контекста соответствующего соглашения не вытекает иное), при этом национальное определение, изложенное в налоговых законах, согласно принципу отраслевого приоритета, имеет безусловный приоритет над определениями, содержащимися в иных актах национального законодательства, за исключением вышестоящих.

Необходимо отметить, что в Российском законодательстве все-таки присутствует аналог понятия «бенефициарный собственник»,- это, введенное в Налоговый кодекс Российской Федерации с ноября 2014 года определение «лица, имеющего фактическое право на доходы».

Годом ранее в Федеральный закон от 07.08.2001 № 115-Ф3 «О противодействии легализации (отмыванию) доходов, полученных преступным путем, и финансированию терроризма» было введено понятие «бенефициарный владелец», под которым подразумевается физическое лицо, которое в конечном счете, прямо или косвенно (через третьих лиц) владеет (имеет преобладающее участие более 25 процентов в капитале) клиентом - юридическим лицом либо имеет возможность контролировать действия клиента.

Согласно второму пункту седьмой статьи Налогового кодекса Российской Федерации «лицом, обладающим фактическим правом на доходы» признается лицо, а также инностранная структура без образования лица, которое в силу прямого, либо косвенного участия в деятельности организации, либо контроля над организацией, либо в силу иных обстоятельств имеет право самостоятельно пользоваться или распоряжаться доходом, полученным данной соответствующей организации.

При этом, как следует из разъяснений, содержащихся в Письме Министерства Финансов Российской Федерации от 09.04.2014 № 03-00-Р3/16236 «О применении льгот, предусмотренных международными соглашениями об избежании двойного налогообложения», предоставление налоговых льгот в государстве-источнике выплачиваемого иностранному лицу дохода (сниженных ставок и освобождений) также не соответствует целям и задачам международных соглашений, в случае, если получатель такого дохода, не используя такие инструменты, как номинальное держание, либо агентирование, стает действовать в качестве посредника (промежуточного звена) в интересах иного лица, фактически являющегося выгодоприобретателем от соответствующего дохода.

Подобная промежуточная структура, (например кондуитная компания), не может считаться лицом, обладающим фактическим правом на получаемый доход, если, несмотря на свой формальный статус владельца такого дохода в гражданско-правовой сделке с лицом, являющимся налоговым резидентом государства-источника дохода, данная компания имеет крайне ограниченные полномочия, что позволяет рассматривать ее как доверенное лицо, либо как управляющего, осуществляющего свои действия от имени других лиц. Кроме того, с 2017 года иностранная компания, имеющая фактическое право на получение дохода, обязана предоставлять налоговому агенту, выплачивающему такой доход, документ, подтверждающий постоянное место нахождение получателя такого дохода на территории иностранного государства, с которым у России заключено соглашение об исключении двойного налогообложения (пункт 1 статья 312 Налогового кодекса Российской Федерации).

Принимая во внимание выше изложенное, необходимо отметить, что в российском праве взаимосвязанные понятия «бенефициарный владелец» и «бенефициарная собственность» имеют экономическое, а не цивилистическое происхождение [4], и, несмотря на отсутствие формализованного закрепления данных понятий в законодательстве, они получили довольно широкое применение при вынесении судебных решений по гражданским делам. В данном ключе можно считать показательным Решение, вынесенное Мещанским районным судом города Москвы от 31.01.2012 по делу № 2-1427/2012 (2-10783/2011), в рамках которого рассматривался иск компании «Дейлмонт Лимитед» к гражданину С., а также к ряду российских и иностранных юридических лиц о взыскании задолженности, возник- 
шей вследствие поручительства по кредитному договору, с российским банком (Соответствующее Решение Мещанского районного суда города Москвы опубликовано не было, суждения о нем основываются на описательной части определения апелляционной инстанции, постановлении кассационной инстанции и определения Верховного Суда РФ). Забегая вперед, стоит отметить, что Решение первой инстанции по данному делу было поддержано апелляцией и кассацией, однако Верховный суд отменил решение данных судебных инстанций в части ообращения взыскания на право аренды, а также на здание, принадлежащее третьему лицу[5].

Коротко суть упомянутого дела заключалось в том, что между ООО «МИАН Холдинг» (позднее переименованным в ООО «Левангер») и ОАО «Альфа-Банк» было заключено соглашение о предоставлении кредита в иностранной валюте. Кроме того аналогичное соглашение было подписано и между «Альфа-Банком» и ООО «Олдфин» (позднее сменившим название на ООО «Ортона»). Для обеспечения обязательств перечисленных юридических лиц между «Альфа-Банком» и гражданином С. были заключены договоры поручительства. Затем «Альфа-Банк» уступил свои права по указанным договорам кредитования и поручительства зарегистрированной на Кипре компании «Дейлмонт Лимитед», а уже после этого по причине неисполнения своих обязательств заемщиками с выше упомянутого гражданина С., имевшего неосторожность выступить поручителем по указанным договорам, Решениями Мещанского районного суда города Москвы в 2010 году была взыскана соответствующая задолженность. Однако, по причине недостаточности имущества, принадлежащего гражданину С., а также в силу наличия задолженности данного гражданина перед компанией «Дейлмонт Лимитед» по сводному исполнительному производству, «Дейлмонт Лимитед» и была вынуждена обратиться в суд с иском о взыскании с юридических лиц -получателей валютных кредитов, поручителем по которым выступил гражданин C.

В результате рассмотрения дела, судебные органы установили, что гражданин С. фактически являлся бенифициарным владельцем недвижимого имущества, зарегистрированного на ряд юридических лиц, иными словами являлся фактическим обладателем данного имущества.

В рамках рассмотрения дела, соответчики - все перечисленные в иске «Дейлмонт Лимитед» юридические лица, на имущество которых истец просил обратить взыскание, направили апелляционные жалобы, мотивированые тем, что они не являются надлежащими ответчиками по делу, однако, апелляционный суд указал, что данное утверждение соответчиков опровергается представленными в ходе рассмотрения дела доказа- тельствами, свидетельствующими о том, что гражданин С. посредством цепочки корпоративного контроля в которой соответчики по делу являются заключительными звеньями, является фактическим владельцем недвижимого имущества, на которое суд первой инстанции и обратил взыскание.

Примечательно, что судебными органами в рамках кассации, апелляции и надзора рассмотрения упомянутого дела было отдельно отмечено, что поскольку понятие «собственник», или «бенефициар», закрепленное в ратифицированной Россией Конвенции ООН, является ообщеизвестным, а при этом Положением Центрального банка Российской Федерации введено понятие конечного собственника акций, суд правомерно использовал данные понятия при вынесении решения и пришел к правильному выводу о том, что гражданин С. является конечным владельцем имущества, на которое истец просил обратить взыскание. Суд установил, что цепочка корпоративного контроля представляла собой следующее:

- единственным бенефициаром двух компаний «Р» и «С», зарегистрированных а юрисдикции Британских Виргинских островов, является гражданин С, а номинальным руководителем и акционером данных компаний является гражданка Л., постоянно проживающая в Республике Кипр. Между гражданкой Л. и гражданином С. заключен договор доверительного управления, по которому гражданка Л. является держателем акций компаний в пользу гражданина С. и соглашается принимать письменные указания и поручения исключительно от гражданина С. либо от лиц, им уполномоченных;

- упомянутые компании «Р» и «С» с Виргинских островов выступают единственными учредителями фонда «Хелиос Инвестментс Фондайшен», зарегистрированного на уже на острове Джерси и единственным бенефициаром которого также является гражданин С.;

- указанный фонд «Хелиос Инвестментс Фондайшен» выступает в качестве единственного участника следующей, также офшорной, но уже Кипрской компании «Джинталекс Холдингз ЛтД»;

- в свою очередь кипрская «Джинталекс Холдингз ЛТД» является единственным акционером 10 компаний, снова зарегистрированных на Британских Виргинских островах, а уже эти 10 компаний являются владельцами следующих в цепочке 10 компаний, зарегистрированных на Кипре;

- и уже кипрские десять компаний являются единственными учредителями и участниками восьми обществ с ограниченной ответственностью, прописанных на территории Российской Федерации, и являющихся владельцами активов гражданина 
C. в России, включая недвижимое имущество и имущественные права.

Изучив приведенную цепочку владения, суды в рамках упомянутого дела в частности указали, что акциями и долями юридических лиц, на которых оформлено оспариваемое имущество, последовательно владеют номинальные лица, в то время как фактическим действительным обладателем (бенефициаром) данного оспариваемого имущества, на которое подлежит обращению взыскание, является гражданин С.

В результате в судебном порядке, ответственность по долгам гражданина С. была возложена на недвижимое имущество компаний, формальным (номинальным) участником, или учредителем которых данный гражданин не являлся.

Решения судов по приведенному в данном примере делу одни ученые рассматривают в качестве примера использования доктрины «снятия корпоративной вуали» в то время, как другие в качестве применения концепции бенефициарной собственности.

В частности, по мнению профессора Е.А.Суханова, в указанном случае речь идет о попытках использования «обратного», или «перевернутого проникновения», при котором кредиторы участника компании (как правило, единственного) получают возможность обратить взыскание по его личным долгам на имущество контролируемой им компании[6].

С отличным мнением выступает профессор В.А. Канашевский, который считает, что в данном деле российские суды фактически признали концепцию бенефициарной собственности, проистекающую из английского права справедливости [7].

Несмотря на разную оценку решения на предмет применения в нем доктрины «снятия корпоративной вуали» или концепции бенефициарной собственности нельзя отрицать сам факт того, что с законодательной и доктринальной точек зрения рассматриваемый судебный акт весьма прогрессивен, а новизна данного дела заключается в том, что суды пожалуй впервые использовали при рассмотрении подобного рода дел чужеродный для российской правовой системы инструмент, дабы устранить пробел внутрироссийского корпоративного законодательства.

В завершении необходимо отметить, что текущая ситуация во внутрироссийском правовом поле, позволяет предположить, что концепция бенефициарной собственности имеет больше шансов на закрепление и дальнейшее развитие в российском гражданском законодательстве, нежели доктрина «снятия корпоративной вуали», в силу того, что она, в сравнении с последней, не игнорирует самостоятельную личность юридического лица.

\section{ЛИТЕРАТУРА}

1. Федеральный закон от 07 августа 2001 г. N115-Ф3 «0 противодействии легализации (отмыванию) доходов, полученных преступным путем, и финансированию терроризма».

2. Vann R. Beneficial Ownership: Does History (and maybe policy) Tell Us // The University of Sydney Law School: Legal Studies Research Paper. September 2012. N12/66. P. 5-6, 8 .

3. Model Convention with Respect to Taxes on Income and on Capital. URL: https://www.oecd.org/ctp/treaties/articles-model-tax-convention-2017.pdf (дата 06paщения: 10.02.2020).

4. Микрюков В. А. Концепция бенефициарной собственности и бремя деофшоризации российской экономики // Законодательство и экономика. 2014. N7. Доступ из СПС «КонсультантПлюс».

5. Определение Судебной коллегии по гражданским делам Верховного Суда РФ № 5-КГ13-61 от 18.06.2013.

6. Суханов Е. А. Сравнительное корпоративное право. 2-е изд. М.: Статут, 2015. С. 197-198.

7. Канашевский В. А. Офшорные компании и трасты. Антиофшорное регулирование. М., Международные отношения. 2018. С. 193. 